\title{
Candidate gene mutation analysis in bilateral adrenal pheochromocytoma and sympathetic paraganglioma
}

Esther Korpershoek, Bart-Jeroen Petri, Francien $H$ van Nederveen,
Winand $N M_{\text {Dinjens, Albert A Verhofstad }}^{1}$, Wouter $W$ de Herder ${ }^{2}$,
Sonja Schmid ${ }^{3}$, Aurel Perren ${ }^{3}$, Paul Komminoth ${ }^{3}$ and Ronald R de Krijger

Department of Pathology, Josephine Nefkens Institute, Erasmus MC, University Medical Center Rotterdam, JNI room 222, PO Box 2040, 3000 CR Rotterdam, The Netherlands

${ }^{1}$ Departments of Pathology and Internal Medicine, Radboud University Nijmegen Medical Center, Nijmegen, The Netherlands

${ }^{2}$ Department of Internal Medicine, Erasmus MC, University Medical Center, Rotterdam, The Netherlands

${ }^{3}$ Department of Pathology, University Hospital Zürich, Zürich, Switzerland

(Requests for offprints should be addressed to R R de Krijger; Email: r.dekrijger@erasmusmc.nl)

E Korpershoek and B-J Petri contributed equally to this work

\begin{abstract}
Pheochromocytomas (PCCs) are rare tumors that arise from chromaffin tissue in the adrenal medulla, but can also occur in the abdomen outside the adrenals and are then called sympathetic paragangliomas (SPGLs). According to the literature, between 15 and $25 \%$ of apparently sporadic adrenal PCC and SPGL are caused by germline mutations in RET, von Hippel-Lindau disease (VHL), succinate dehydrogenase subunit B $(S D H B)$, or subunit D $S D H D$. However, few studies have addressed the mutation frequency of these candidate genes in selected subgroups of $P C C$ and $\mathrm{SPGL}$, such as bilateral adrenal PCC or extra-adrenal SPGL, and none have looked at somatic mutations by analyzing tumor tissue. Therefore, we have investigated the occurrence of germline and somatic mutations in $R E T, V H L, S D H B$, and $S D H D$ in comparatively large series of bilateral adrenal PCC $(n=$ 33 patients) and SPGL ( $n=26$ patients), with the aim of determining the mutation frequency of each of these genes and to establish a genetic testing algorithm. Twenty-one RET, two VHL germline, and one SDHD mutations were found in the patients with bilateral adrenal PCC. In SPGL, one novel SDHB germline and one novel $S D H B$ somatic mutation were observed. In addition, two $S D H D$ germline mutations were found. We conclude that germline $R E T$ mutations are predominantly found in bilateral PCC, and that somatic and germline SDHB and SDHD mutations usually occur in SPGL, which has practical consequences for genetic testing algorithms. We suggest that sequential mutation analysis should be directed first at $R E T$, followed by $V H L$ and $S D H D$ for patients with bilateral adrenal PCC at diagnosis, and at $S D H B$ and $S D H D$ for patients with SPGL.
\end{abstract}

Endocrine-Related Cancer (2007) 14 453-462

\section{Introduction}

Pheochromocytomas (PCC) are rare catecholamineproducing tumors that arise from chromaffin cells of the adrenal medulla, but can also occur outside the adrenal in the abdomen, and are then called sympathetic paragangliomas (sPGL; Lenders et al. 2005). Pheochromocytoma-associated syndromes include multiple endocrine neoplasia type 2 (MEN2), von Hippel-Lindau disease (VHL), neurofibromatosis-1, and the familial pheochromocytomaparaganglioma (PCC-PGL) syndrome (Neumann et al. 2002). MEN2 is characterized by medullary thyroid carcinoma (MTC) in association with PCC and has three clinical variants, MEN2A, familial medullary thyroid carcinoma (FMTC), and MEN2B (Thakker 2001). The syndrome is caused by germline mutations of the RET proto-oncogene, which are mostly (80-96\%) found in RET exons 10, 11, and 16 (Thakker 2001, Peczkowska \& Januszewicz 2005). Somatic RET mutations have also been found in sporadic PCC affecting exons 10, 11, and 16 (van der Harst et al. 1998b). 
The VHL syndrome is an autosomal dominantly inherited tumor syndrome, with a prevalence of 2-3 per 100000 individuals (Roman 2004). Patients with VHL syndrome have predisposition to develop retinal and central nervous system hemangioblastomas, clear cell renal cell carcinomas, PCC, pancreatic cysts and islet cell tumors, cystadenomas of the epididymis, and endolymphatic sac tumors (Gimm 2005). Both germline and somatic VHL mutations have been found in PCC, which include missense, nonsense, splice-site mutations, and small intragenic and large deletions, but most VHL patients with PCC have missense mutations (Neumann et al. 2002, Dannenberg et al. 2003, Gimm 2005).

The PCC-PGL syndrome is caused by mutations in subunits of the mitochondrial complex II, also known as succinate dehydrogenase (SDH), which is involved in the electron transport chain and the Krebs cycle. SDH consists of a flavoprotein (SDHA), an iron-sulfur protein (SDHB), and two anchoring membranespanning polypeptides (SDHC and SDHD; Ackrell 2002). Apart from $S D H A$, which is related to a rare neurodevelopmental disorder called Leigh syndrome, all three $S D H$ genes have been implicated in the occurrence of PGL. While SDHC has only infrequently been described and exclusively in the context of head and neck PGL, $S D H B$ and $S D H D$ are also associated with abdominal (sympathetic) PGL and adrenal PCC. $S D H B$ mutation carriers present predominantly with sPGL, often with a malignant phenotype, although adrenal PCC and head and neck PGL may occur. $S D H D$ mutation carriers present more head and neck PGL and, at a lower frequency, adrenal PCC and abdominal sPGL, which are almost always benign (Baysal et al. 2002, Neumann et al. 2004, Amar et al. 2005, Benn et al. 2005, Schiavi et al. 2005).

In VHL disease and the MEN2 syndrome, PCC often have a bilateral adrenal presentation and are occasionally found at extra-adrenal sites (Bryant et al. 2003, Lenders et al. 2005, Machens et al. 2005). In contrast, patients with a germline $S D H B$ mutation present with extra-adrenal catecholamine-producing tumors in $50 \%$ of cases. Germline $S D H D$ mutation carriers also develop extra-adrenal catecholamine-producing tumors (sPGL), and present with bilateral adrenal PCC (Gimenez-Roqueplo et al. 2003, Maier-Woelfle et al. 2004, Neumann et al. 2004, Amar et al. 2005, Benn et al. 2005).

Although knowledge about genotype-phenotype relationships has improved for germline RET, VHL, $S D H B$, and $S D H D$ mutations, only few studies have addressed mutations of these $P C C$-causing genes in specific series of bilateral PCC and/or sPGL. In addition, there are no studies that have compared tumor tissue and the corresponding normal tissue for the detection of somatic mutations. To determine the mutation frequency for each of these four candidate genes in a large subset of patients, we have selected 33 patients with bilateral PCC and 26 patients with sPGL, to screen for germline and somatic mutations in RET exons $10,11,13,14,15$, and 16 , and in all exons of $V H L, S D H B$, and $S D H D$ genes. In addition, we discuss the significance of $S D H B$ and $S D H D$ sequence abnormalities.

\section{Materials and methods}

\section{Patients}

Tissue specimens were retrieved from the archives of the Department of Pathology of the Erasmus MC (Rotterdam, The Netherlands), The University Medical Center St Radboud (Nijmegen, The Netherlands), and the University Hospital Zürich (Zürich, Switzerland) following approval of the experimental design and protocols by the Erasmus MC Medical Ethical Committee. These are all tertiary referral centers for endocrine tumor syndromes. A series of 33 bilateral PCCs and 26 sPGLs was selected for mutation analysis of RET exons 10,11,13-16 and the entire coding sequence of $V H L, S D H B$, and $S D H D$. Of the 33 patients with bilateral PCC, 2 patients had metastases and 31 patients had no metastases. Twenty-six patients with sPGL were selected, of which 15 patients had metastases and 11 patients had no metastases. All samples were coded, so that patient identity was unknown to the investigator. However, a set of clinical data corresponding to the tumor samples was available for further analysis. Throughout this paper, the extraadrenal catecholamine-producing tumors from the abdomen are designated sPGL. Malignancy was defined as the presence of (distant) metastases at sites where chromaffin tissue is not normally present.

\section{Tissue preparation}

Initially, mutation analysis was carried out on tumor DNA. Corresponding normal DNA was used to determine whether a mutation was also present in the germline. DNA was isolated from paraffin-embedded tissues or snap-frozen tissues whenever available, using Puregene (Gentra, Minneapolis, MN, USA), according to manufacturers' instructions. The exclusive presence of tumor tissue was confirmed by making control slides prior to DNA extraction. Positive controls from patients with known mutations and negative controls from normal individuals were included in all experiments. 


\section{Denaturating gradient gel electrophoresis (DGGE)}

PCR with genomic DNA as template was carried out in a $50 \mu \mathrm{l}$ mixture of $1 \times$ PCR buffer (Perkin-Elmer Europe, Rotkreuz, Switzerland) containing 10-400 ng template DNA, $200 \mu \mathrm{M}$ of each intron-based primer (Table 1), and $1 \mu \mathrm{Taq}$ polymerase (Ampli Taq Gold, PerkinElmer Europe). After a hot start of $7 \mathrm{~min}$ at $95^{\circ} \mathrm{C}$, a 'touch-down' procedure was used consisting of denaturation for $60 \mathrm{~s}$ at $95{ }^{\circ} \mathrm{C}$, annealing for $60 \mathrm{~s}$ at temperatures decreasing from 60 to $55^{\circ} \mathrm{C}$ during the first
11 cycles (with $0.5^{\circ} \mathrm{C}$ decremental steps in cycles $2-11$ ), and ending with an extension step for $60 \mathrm{~s}$ at $72{ }^{\circ} \mathrm{C}$. Ten cycles with an annealing temperature of $55^{\circ} \mathrm{C}$ and 15 cycles with an annealing temperature of $45^{\circ} \mathrm{C}$ followed with extension times of $90 \mathrm{~s}$. After a final extension for $10 \mathrm{~min}$ at $72{ }^{\circ} \mathrm{C}$, heteroduplex formation was induced by initial denaturation at $98^{\circ} \mathrm{C}$ for $10 \mathrm{~min}$ followed by incubations at $55^{\circ} \mathrm{C}$ for $30 \mathrm{~min}$ and $37^{\circ} \mathrm{C}$ for $30 \mathrm{~min}$. For DGGE, $10 \mu \mathrm{l}$ PCR product in $3 \mu \mathrm{l}$ Ficoll-based loading buffer were loaded onto $10 \%$ polyacrylamide gels containing a urea-formamide gradient in $0.5 \times$

Table 1 Primers used for mutation analysis

\begin{tabular}{|c|c|c|c|c|}
\hline & Forward $\mathbf{5}^{\prime} \rightarrow \mathbf{3}^{\prime}$ & Reverse $\mathbf{5}^{\prime} \rightarrow \mathbf{3}^{\prime}$ & $\begin{array}{l}\text { Product } \\
\text { size }(b p)\end{array}$ & $\begin{array}{l}\text { Mutation } \\
\text { analysis } \\
\text { method }\end{array}$ \\
\hline RET 10 & GCGCCCCAGGAGGCTGAGTG & $\begin{array}{l}\text { cgcccgccgcgccccgegcccgtcccgccgcccccg- } \\
\text { cgTGGTGGTCCCGGCCGCC }\end{array}$ & 225 & DGGE \\
\hline RET 11 & CTCTGCGGTGCCAAGCCTCA & $\begin{array}{l}\text { cgcccgccgcgccccgcgcccggcccgccgecccc- } \\
\text { gcccgGAGTAGCTGACCGGGAAGGC }\end{array}$ & 262 & DGGE \\
\hline RET 13 & CTCAAGCAGCATCGTCTTTG & AAGGGAGAAAGAGGGAGAAC & 328 & SSCP \\
\hline RET 14 & GGTTCAAGAGAAAGCTGAGG & CTAGAGTGTGGCATGGTGG & 524 & SEQ \\
\hline RET 15 & CTCTGCTGGTCACACCAGG & CGGTATCTTTCCTAGGCTTC & 296 & SSCP \\
\hline RET 16 & $\begin{array}{l}\text { cgcccgccgcgecccgcgcccggeccgecgcccccgcccga- } \\
\text { aataataaaAGGGATAGGGCCTGGGCTTC }\end{array}$ & ACCCCAAGAGAGCAACACCC & 224 & DGGE \\
\hline VHL $1 a$ & gcgcgcgAGCGCGTTCCATCCTCTAC & $\begin{array}{l}\text { cgcccgccgcgccccgcgcccggcccgccgccccc- } \\
\text { gcccgAGGGCCGTACTCTTCGAC }\end{array}$ & 255 & DGGE \\
\hline$V H L 1 b$ & gcgcgGCGGAGAACTGGGACGAG & $\begin{array}{l}\text { cgcccgccgcgecccgegcccggcccgccgccccc- } \\
\text { gcccgGCTTCAGACCGTGCTATCGT }\end{array}$ & 418 & DGGE \\
\hline$V H L 2$ & $\begin{array}{l}\text { cgcccgccgcgecccgcgcccggeccgecgeccccgcccga- } \\
\text { aataataaaCTTTAACAACCTTGCTT }\end{array}$ & cgtcccgcGTCTATCCTGTACTTACCAC & 266 & DGGE \\
\hline$V H L 3$ & gcgcgTTCCTTGTACTGAGACCCTAGT & $\begin{array}{l}\text { cgcccgccgcgccccgcgcccggcccgccgccccc- } \\
\text { gcccgAGCTGAGATGAAACAGTGTAA- } \\
\text { GT }\end{array}$ & 316 & DGGE \\
\hline SDHB 1 & GAGCGACCTCGGGGTTAAG & GCTTTCCTGACTTTTTCCСTC & 157 & SSCP \\
\hline SDHB 2 & $\begin{array}{l}\text { cgcccgccgcgecccgcgcccggeccgecgeccccgcccgT- } \\
\text { TTTTCCTTTTTGTGAACTTT }\end{array}$ & AAGCATGTCCCTAAATCAAA & 265 & DGGE \\
\hline SDHB 3 & $\begin{array}{l}\text { cgcccgccgcgccccgcgcceggcccgccgcccccgcccG- } \\
\text { GAACTTTACATAAATACCACTGGA }\end{array}$ & cgCTATCAGCTTTGGCCAGC & 242 & DGGE \\
\hline SDHB 4 & $\begin{array}{l}\text { cgcccgccgcgecccgcgcccggcccgccgcccccgcccga- } \\
\text { aataataaaTGATTCCGGATATGGGTGAG }\end{array}$ & cgtcccgcCCCCCATGCAAATAAAAACA & 256 & DGGE \\
\hline SDHB 5 & gcgcgTGATGATGGAATCTGATCCT & $\begin{array}{l}\text { cgcccgccgegcccegcgcccggcccgccgccccc- } \\
\text { gcccgaaataataaaCAGATTGAAACAAT- } \\
\text { AAATAGGGA }\end{array}$ & 261 & DGGE \\
\hline$S D H B 6$ & $\begin{array}{l}\text { cgcccgccgcgecccgcgcccggeccgecgcccccgcccga- } \\
\text { aataataaลCCTCTCTTTTCTCCCCATAC }\end{array}$ & cgCAGCAATCTATTGTCCTCTTG & 252 & DGGE \\
\hline SDHB 7 & gcgcgAGCTAATCATCCCTGGTTTT & $\begin{array}{l}\text { cgcccgccgcgccccgcgcccggcccgccgccccc- } \\
\text { gcccgaaataataaaTTGTGAGCACATGC- } \\
\text { TACTTC }\end{array}$ & 270 & DGGE \\
\hline$S D H B 8$ & $\begin{array}{l}\text { cgcccgccgegccccgcgeccggeccgccgcccccgcccgG- } \\
\text { TGGGTTTTCCCTTTCAGTT }\end{array}$ & $\begin{array}{l}\text { cgcccgccgcgeccegcgeccggcccgccgecccc- } \\
\text { gcccgGTGGGTTTTCCCTTTCAGTT }\end{array}$ & 361 & DGGE \\
\hline$S D H D 1$ & $\begin{array}{l}\text { cgcccgccgcgecccgcgcccggcccgecgcccccgcccga- } \\
\text { aataataaaTGACCTTGAGCCCTCAGGAACG }\end{array}$ & gcgcgTCAGGGTGGGAAGACCCCT & 153 & DGGE \\
\hline$S D H D 2$ & GATCATCCTAATGACTCTTTCC & AGCAGCAGCGATGGAGAGAA & 168 & SSCP \\
\hline$S D H D 3$ & $\begin{array}{l}\text { cgcccgccgcgecccgcgeccggeccgecgeccccgcccgC- } \\
\text { TTTTATGAATCTGGTCCTTTTTG }\end{array}$ & gcgcgCAACTATATTTGGAATTGCTATAC & 245 & DGGE \\
\hline SDHD 4 & $\begin{array}{l}\text { cgcccgccgegccccgcgcceggcccgccgcccccgccegT- } \\
\text { GATGTTATGATTTTTTCTTTTTCT }\end{array}$ & gcgcgCAATTCTTCAAAGTATGAAGTCA & 269 & DGGE \\
\hline
\end{tabular}


Tris-acetate-EDTA (TEA). The amplicons were electrophoresed at $60{ }^{\circ} \mathrm{C}$ and $100 \mathrm{~V}$ for $16 \mathrm{~h}$. DNA strands were visualized using silver staining as described previously (Komminoth et al. 1994).

\section{Single-strand conformation polymorphism (SSCP) analysis}

PCR amplification of tumor DNA was performed with $10-100 \mathrm{ng}$ DNA in a final volume of $15 \mu \mathrm{l}$ containing $1.5 \mathrm{mM} \mathrm{MgCl} 2,10 \mathrm{mM}$ Tris $-\mathrm{HCl}, 50 \mathrm{mM} \mathrm{KCl}$, $0.02 \mathrm{mM}$ dATP, $0.2 \mathrm{mM}$ dGTP, dTTP and dCTP, $0.8 \mu \mathrm{Ci} \quad \alpha^{32} \mathrm{P}$-dATP (Amersham), $15 \mathrm{pmol}$ of each forward and reverse primer (Table 1), and $3 \mathrm{U}$ Taq polymerase (Ampli Taq Gold, Perkin-Elmer Europe). PCR was performed for 35 cycles at $95{ }^{\circ} \mathrm{C}$ for $30 \mathrm{~s}$, $55^{\circ} \mathrm{C}$ for $45 \mathrm{~s}$, and $72{ }^{\circ} \mathrm{C}$ for $1 \mathrm{~min}$, followed by 1 cycle at $72{ }^{\circ} \mathrm{C}$ for $10 \mathrm{~min}$. PCR products were electrophoresed overnight at $8 \mathrm{~W}$ on a nondenaturing gel, containing $8 \%$ polyacrylamide ((49:1) Fluka, Neu-Ulm, Germany) and $10 \%$ glycerol $(\mathrm{v} / \mathrm{v})$. After electrophoresis, the gel was dried and exposed to an X-ray film.

\section{DNA sequencing}

All samples demonstrating aberrant patterns in the DGGE or SSCP analysis were sequenced. PCR was performed in a final volume of $50 \mu \mathrm{l}$ under identical conditions as the previous PCR, except that this mix contained $0.2 \mathrm{mM}$ dNTPs instead of $0.02 \mathrm{mM}$ dATPs and $0.8 \mu \mathrm{Ci} \alpha^{32} \mathrm{P}-\mathrm{dATP}$. The PCR products were purified using nucleospin Extract II (MachereyNagel, Düren, Germany) according to manufacturers' instructions. The purification was followed by a sequence reaction using the Bigdye Terminator V3.1 cycle sequencing kit (Applied Biosystems, Foster City, CA, USA). To $1 \mu \mathrm{l}$ purified PCR product, $2 \mu 1$ Termination Ready Reaction mix, $2 \mu 1$ of $5 \times$ sequencing buffer, $1 \mu \mathrm{l}$ forward or reverse primer (13.2 $\mathrm{pM}$ ), and $14 \mu \mathrm{l}$ deionized water were added. The cycle Sequencing program was performed for 25 cycles at $96{ }^{\circ} \mathrm{C}$ for $10 \mathrm{~s}, 50{ }^{\circ} \mathrm{C}$ for $5 \mathrm{~s}$ and $60{ }^{\circ} \mathrm{C}$ for $4 \mathrm{~min}$. This was followed by a precipitation step, adding $13 \mu \mathrm{l}$ deionized water, $3 \mu \mathrm{l}$ of $3 \mathrm{M} \mathrm{NaAc}(\mathrm{pH}$ 5.2 ), and $64 \mu \mathrm{l}$ ethanol (100\%) to the sequence reaction product and incubating overnight at room temperature before centrifuging for $20 \mathrm{~min}$ at 14000 r.p.m. After washing the samples with $70 \%$ ethanol and centrifuging them for $10 \mathrm{~min}$ at $14000 \mathrm{~g}$, the pellets were resuspended in $20 \mu \mathrm{l}$ formamide (Applied Biosystems, Warrington, UK). Products were analyzed on the ABI Prism 3100 genetic analyzer (Applied Biosystems).

\section{Results}

\section{Bilateral adrenal PCC}

The series of bilateral adrenal PCC encompassed 31 patients with benign PCC and 2 patients with malignant PCC. The results of the mutation analysis are summarized in Table 2. Twenty-one patients ( 8 males and 13 females) with germline mutations in the RET proto-oncogene were identified in this group (average age 37 years), of which 15 were located in exon 11 (codon 634), 4 in exon 10 (codons 611 and 620), and 2 in exon 16 (codon 918; Fig. 1). No mutations were found in RET exons 13, 14, and 15. All of the RET mutation carriers had benign PCC. After mutation analyses was performed, it was revealed that 12 patients with RET mutations belonged to four families (with 5, 3, 2, and 2 patients; see Table 2). We did not have clinical information about familial occurrence in four of the RET mutation-positive cases. The mutation analysis showed two patients with R64P germline mutations in exon 1 of the $V H L$ tumor suppressor gene and both had no metastasis. These patients belonged to the same family. In addition, one D92Y mutation was found in exon 3 of the $S D H D$ gene. Thus, if we consider each family as a single entity, we would have 14 index patients with bilateral PCC, in whom we found 12 RET mutations, 1 VHL mutation, and 1 SDHD mutation.

None of the patients with bilateral adrenal PCC had mutations in $S D H B$. However, three heterozygous polymorphisms were found in $S D H B$ or $S D H D$ in two patients harboring a RET C634R mutation. These included A6A in exon 1 of $S D H B$, and H50R and S68S in exons 2 and 3 of $S D H D$ respectively. On one occasion, $S D H B$ A6A and SDHD H50R were present in the same patient (Table 3).

Three patients had metachronous appearance of their bilateral PCC. These patients included one with a C634Y mutation who developed PCC with a 3-year interval, and two patients who did not have mutations in RET, VHL, SDHB, or SDHD, which developed PCC with a 4- and 6-year interval. Twenty-seven of the patients with bilateral PCC had synchronous PCC.

\section{Sympathetic PGL}

The sPGL included 11 benign and 15 malignant tumors. The results are summarized in Table 2 . Mutation analysis of RET and VHL did not show any abnormalities in the 26 patients with sPGL. In contrast, three aberrations were detected in $S D H B$ exons 4,5 , and 7. The first aberration revealed a novel mutation, $\mathrm{S} 100 \mathrm{~F}$ in exon 4 , which was not present in normal 
Table 2 Summary of results of bilateral pheochromocytoma mutation carriers

\begin{tabular}{|c|c|c|c|c|c|c|c|c|}
\hline Patient & $\operatorname{Sex}^{a}$ & $\begin{array}{c}\text { Age } \\
\text { (years) }\end{array}$ & $\mathbf{b} / \mathbf{m}^{\mathrm{b}}$ & Gene & $\begin{array}{c}\text { Nucleotide change } \\
\text { mutation/polymorphism }\end{array}$ & $\begin{array}{l}\text { Amino acid change } \\
\text { polymorphism }\end{array}$ & Family & $\begin{array}{l}\text { Follow-up } \\
\text { (years) }\end{array}$ \\
\hline F6 & $\mathrm{m}$ & 31 & $\mathrm{~b}$ & $V H L$ & $\mathrm{CGC} \rightarrow \mathrm{CCC}$ & R64P & $A$ & 21 \\
\hline F28 & $\mathrm{m}$ & 29 & $\mathrm{~b}$ & $\begin{array}{l}R E T \\
S D H B \\
S D H D\end{array}$ & $\begin{array}{l}\mathrm{TGC} \rightarrow \mathrm{CGC} \\
C A C \rightarrow C C C^{\mathrm{C}} \\
C A C \rightarrow C G C^{\mathrm{C}}\end{array}$ & $\begin{array}{c}\text { C634R } \\
A 6 A^{\mathrm{c}} \\
H 50 R^{\mathrm{C}}\end{array}$ & D & 26 \\
\hline F37 & $f$ & 32 & $b$ & $R E T$ & $\mathrm{TGC} \rightarrow \mathrm{CGC}$ & C634R & B & 24 \\
\hline F38 & $\mathrm{m}$ & 42 & $b$ & $R E T$ & $\mathrm{TGC} \rightarrow \mathrm{CGC}$ & C634R & $B$ & 22 \\
\hline F39 & $f$ & 42 & $\mathrm{~b}$ & $R E T$ & $\mathrm{TGC} \rightarrow \mathrm{CGC}$ & C634R & $\mathrm{C}$ & 24 \\
\hline $\mathrm{F} 41$ & $\mathrm{~m}$ & 16 & $b$ & $\begin{array}{c}R E T \\
S D H D\end{array}$ & $\begin{aligned} \mathrm{TGC} & \rightarrow \mathrm{CGC} \\
A G C & \rightarrow A G T^{\mathrm{C}}\end{aligned}$ & $\begin{array}{l}\text { C634R } \\
\text { S68S }^{c}\end{array}$ & $\mathrm{D}$ & 21 \\
\hline $\mathrm{F} 42$ & $f$ & 29 & $b$ & $R E T$ & $\mathrm{TGC} \rightarrow \mathrm{CGC}$ & C634R & $\mathrm{D}$ & 24 \\
\hline F65 & $\mathrm{m}$ & $\mathrm{u}$ & $b$ & $R E T$ & $\mathrm{TGC} \rightarrow \mathrm{CGC}$ & C634R & $E$ & $\mathrm{u}$ \\
\hline F78 & $f$ & 29 & $\mathrm{~b}$ & $R E T$ & $\mathrm{TGC} \rightarrow \mathrm{CGC}$ & C620R & & 2 \\
\hline F79 & $\mathrm{m}$ & 26 & $\mathrm{~b}$ & $R E T$ & $\mathrm{TGC} \rightarrow \mathrm{CGC}$ & C634R & $E$ & 14 \\
\hline F80 & $f$ & 18 & $\mathrm{~b}$ & $R E T$ & $\mathrm{TGC} \rightarrow \mathrm{CGC}$ & C634R & B & 14 \\
\hline F82 & $f$ & 24 & $b$ & $R E T$ & $\mathrm{TGC} \rightarrow \mathrm{CGC}$ & C634R & B & $\mathrm{u}$ \\
\hline F84 & $f$ & 50 & b & $R E T$ & $\mathrm{TGC} \rightarrow \mathrm{CGC}$ & C634R & B & 11 \\
\hline F87 & $\mathrm{m}$ & 24 & $\mathrm{~b}$ & $V H L$ & $\mathrm{CGC} \rightarrow \mathrm{CCC}$ & $\mathrm{R} 64 \mathrm{P}$ & $A$ & 11 \\
\hline F89 & $f$ & 38 & $\mathrm{~b}$ & $R E T$ & $\mathrm{TGC} \rightarrow \mathrm{CGC}$ & C634R & C & 12 \\
\hline F92 & $f$ & 51 & $\mathrm{~b}$ & $R E T$ & $\mathrm{TGC} \rightarrow \mathrm{TAC}$ & C611Y & - & 12 \\
\hline F102 & $f$ & 27 & $\mathrm{~b}$ & $R E T$ & ATG $\rightarrow$ ACG & M918T & - & 10 \\
\hline F141 & $\mathrm{m}$ & 49 & $\mathrm{~b}$ & $R E T$ & $\mathrm{TGC} \rightarrow \mathrm{TGG}$ & C634W & - & $\mathrm{u}$ \\
\hline $\mathrm{F} 147$ & $f$ & 27 & $\mathrm{~b}$ & $R E T$ & $\mathrm{ATG} \rightarrow \mathrm{ACG}$ & M918T & - & $\mathrm{u}$ \\
\hline F165 & $f$ & 59 & $\mathrm{~b}$ & $R E T$ & $\mathrm{TGC} \rightarrow \mathrm{TAC}$ & C611Y & - & 17 \\
\hline F168 & $\mathrm{m}$ & 72 & $\mathrm{~b}$ & $R E T$ & $\mathrm{TGC} \rightarrow \mathrm{TAC}$ & C611Y & - & $10^{\dagger}$ \\
\hline F184 & $\mathrm{m}$ & 53 & $\mathrm{~b}$ & $R E T$ & $\mathrm{TGC} \rightarrow \mathrm{TAC}$ & C634Y & $\mathrm{F}$ & $2^{\dagger}$ \\
\hline F188 & $f$ & 25 & $\mathrm{~b}$ & $S D H D$ & $\mathrm{GAC} \rightarrow \mathrm{TAC}$ & D92Y & - & 38 \\
\hline F194 & $f$ & 24 & $\mathrm{~b}$ & $R E T$ & $\mathrm{TGC} \rightarrow \mathrm{TAC}$ & C634Y & $\mathrm{F}$ & 9 \\
\hline
\end{tabular}

${ }^{\dagger}$, Deceased.

${ }^{a} \mathrm{~m}$, male; $f$, female.

${ }^{\mathrm{b}} \mathrm{b}$, benign; $\mathrm{m}$, malignant; $\mathrm{u}$, unknown.

${ }^{\mathrm{c}}$ Nucleotide and amino acid changes representing polymorphisms are given in italics.

DNA of the same patient. The sPGL of this 25-year-old female patient was localized in the bladder. The second variant pattern of $S D H B$, in exon 5, was identified as a heterozygous germline S163P substitution, which is described as a rare polymorphism (Cascon et al. 2004). The third $S D H B$ aberration represented the heterozygous mutation $\mathrm{C} 243 \mathrm{~S}$ in exon 7 , which was also present in the corresponding normal DNA (Fig. 2).

Mutation analysis of the SDHD gene showed four abnormal patterns, of which two represented previously described germline mutations (D92Y and L95P). The SDHD D92Y mutation was found in a 52-year-old woman, who had a bilateral adrenal PCC, 27 years earlier, which is in our bilateral series as well (Table 2, patient F188). The L95P mutation was found in a patient with sPGL at multiple abdominal spots. The other two patterns appeared to be the H50R and S68S polymorphisms (Table 3).

There were very few tumors with mutations in this series which prevented us from drawing any conclusions on genotype-phenotype relationships.

\section{Discussion}

It has been reported that patients with RET or VHL germline mutations often present with bilateral adrenal PCC (Bryant et al. 2003, Lenders et al. 2005), and that part of the germline $S D H B$ or $S D H D$ carriers develop sPGL (Gimenez-Roqueplo et al. 2003, Neumann et al. 2004, Dannenberg et al. 2005). However, detailed information about the frequencies of these mutations in patients with bilateral adrenal PCC or sPGL is limited. In addition, there have been virtually no studies based on tumor tissue, which allows the detection of somatic mutations in addition to germline mutations. In the present study, we have investigated tumor tissue and the corresponding normal tissue from a unique series of bilateral PCC and sPGL, predominantly from the Netherlands, for germline and somatic mutations in the above-mentioned PCC susceptibility genes. We found 12 RET, $1 \mathrm{VHL}$, and 1 SDHD germline mutations in the 23 unrelated patients and families with bilateral PCC, and $2 S D H B$ and $2 S D H D$ mutations in the series of 26 sPGLs. 
A

C634R

C634Y
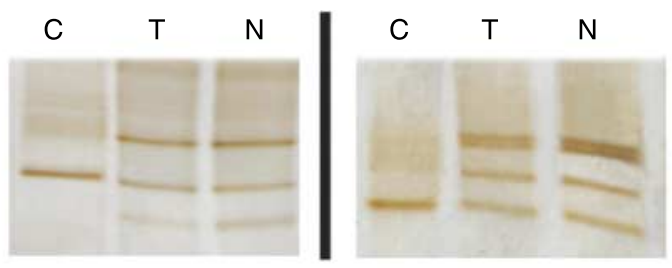

B C611Y

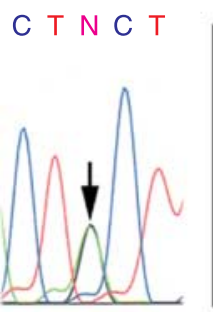

$\mathrm{TGC} \Rightarrow \mathrm{TAC}$
C634R

T G T G C

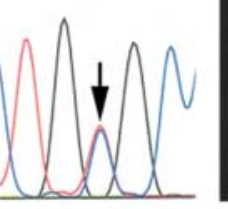

$\mathrm{TGC} \Rightarrow \mathrm{CGC}$
C634Y

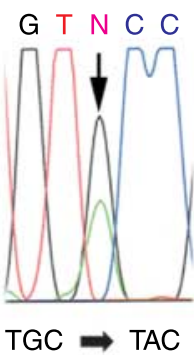

M918T

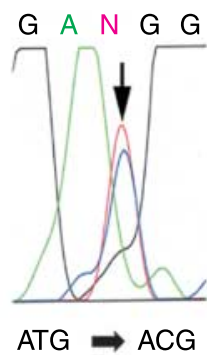

C

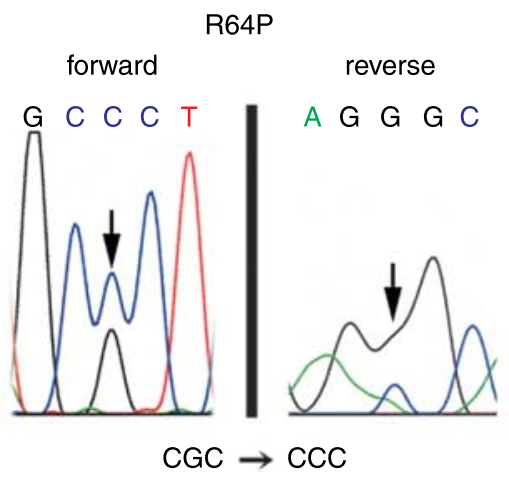

Figure 1 (A) DGGE patterns of healthy control $(\mathrm{C})$, tumor $(\mathrm{T})$, and normal (N) DNA of patients carrying a germline RET C634R or C634Y mutation. (B) Sequence results of four of the six germline RET mutations detected by DGGE mutation analysis: C611Y, C634R, C634Y, and M918T. (C) Forward and reverse sequence of tumor sample carrying the germline VHL R64P mutation found in a patient with bilateral PCC.

The 12 RET mutations encompassed three mutations in codon $611(\mathrm{C} 611 \mathrm{Y})$, one in codon $620(\mathrm{C} 620 \mathrm{R})$, six in codon $634(n=4$ C634R, $n=1$ C634Y, $n=1$ C634W), and two in codon 918 (M918T). All of these mutations have been reported previously (Eng 1996, Machens et al. 2001, Amar et al. 2005). Since other RET mutations have been described in exons 13, 14, and 15 (Peczkowska \& Januszewicz 2005), we performed additional SSCP mutation analyses for these exons on the PCC which were negative for mutations in RET exons 10,11 , or 16 or $V H L$, but no mutations were found. Two patients with bilateral PCC showed the same germline VHL mutation (R64P), and because both patients appeared to be related, they were counted as one patient in our series. These cases were previously reported by van der Harst et al. (1998a).
The patient with the SDHD D92Y germline mutation will be discussed below.

Mutation analysis of the 26 sPGLs showed one novel germline and one novel somatic variant in $S D H B(\mathrm{C} 243 \mathrm{~S}$ and $\mathrm{S} 100 \mathrm{~F}$ ) and two germline mutations in $S D H D$ (D92Y and L95P). The novel $S D H B$ C243S variant was seen in a patient with bone metastasis. We consider the $S D H B$ C243S variant as a pathogenic germline mutation, firstly because loss of the wild-type allele was seen in the sequence analysis results in our study (Fig. 2). Secondly, $S D H B$ C243 is highly conserved throughout many species. Thirdly, two studies report patients who developed a malignant PCC and had a $S D H B$ mutation affecting amino acid R242 (R242H), which is also highly conserved (Young et al. 2002, Neumann et al. 2004). The somatic $S D H B$ S100F variant appeared to be a mutation 
Table 3 Clinical data and mutation analysis results of sympathetic paragangliomas (sPGL)

\begin{tabular}{|c|c|c|c|c|c|c|c|c|c|}
\hline Patient & Sex $^{a}$ & $\begin{array}{c}\text { Age } \\
\text { (years) }\end{array}$ & $\mathrm{b} / \mathrm{m}^{\mathrm{b}}$ & Gene & $\begin{array}{c}\text { Nucleotide } \\
\text { change } \\
\text { mutation/ } \\
\text { polymorphism }^{c}\end{array}$ & $\begin{array}{c}\text { Amino acid } \\
\text { change } \\
\text { polymorphism }\end{array}$ & $\begin{array}{l}\text { Location } \\
\text { SPGL }\end{array}$ & $\begin{array}{c}\text { Location } \\
\text { metastasis }\end{array}$ & $\begin{array}{c}\text { Follow-up } \\
\text { (years) }\end{array}$ \\
\hline $\mathrm{F} 4$ & $f$ & 39 & $\mathrm{~m}$ & & - & - & Abdomen & Lung, lymph node & $4^{\dagger}$ \\
\hline F5 & $f$ & 70 & $\mathrm{~m}$ & & - & - & $\mathrm{u}$ & $\mathrm{u}$ & $1^{\dagger}$ \\
\hline F7 & $f$ & 23 & $\mathrm{~m}$ & & - & - & Abdomen & Bone & $6^{\dagger}$ \\
\hline $\mathrm{F} 10$ & $\mathrm{~m}$ & 41 & $\mathrm{~m}$ & & - & - & Bladder & Lymph node & $6^{\dagger}$ \\
\hline $\mathrm{F} 12$ & $\mathrm{~m}$ & 25 & $\mathrm{~m}$ & $S D H D$ & $\mathrm{CTG} \rightarrow \mathrm{CCG}$ & L95P & Abdomen & Lymph node & 11 \\
\hline $\mathrm{F} 13$ & $\mathrm{~m}$ & 64 & $\mathrm{~m}$ & & - & - & Abdomen & Lung, Brain & $2^{\dagger}$ \\
\hline F15 & $\mathrm{m}$ & 42 & $\mathrm{~m}$ & & - & - & Abdomen & Lung & $\mathrm{u}$ \\
\hline F29 & $f$ & 62 & $\mathrm{~b}$ & & - & - & $\mathrm{u}$ & - & $\mathrm{u}$ \\
\hline F54 & $\mathrm{m}$ & 56 & $\mathrm{~b}$ & $\begin{array}{l}S D H B \\
S D H D\end{array}$ & $\begin{array}{l}T C T \rightarrow C C T^{\mathrm{C}} \\
C A C \rightarrow C G C^{\mathrm{C}}\end{array}$ & $\begin{array}{l}S 163 P^{c} \\
H 50 R^{C}\end{array}$ & Thorax & - & $13^{\dagger}$ \\
\hline F81 & $f$ & 55 & $b$ & & - & - & Thorax & - & 11 \\
\hline F83 & $\mathrm{m}$ & 47 & $b$ & & - & - & Abdomen & - & $\mathrm{u}$ \\
\hline F88 & $\mathrm{m}$ & 79 & $b$ & & - & - & Abdomen & - & $5^{\dagger}$ \\
\hline F122 & $f$ & 43 & $b$ & & - & - & Abdomen & - & $\mathrm{u}$ \\
\hline F138 & $f$ & 70 & $\mathrm{~b}$ & & - & - & Abdomen & - & $\mathrm{u}$ \\
\hline $\mathrm{F} 140$ & u & $\mathrm{u}$ & $\mathrm{m}$ & & - & - & Abdomen & Lung & 5 \\
\hline $\mathrm{F} 160$ & $f$ & 25 & $\mathrm{~b}$ & $S D H B$ & TCT $\rightarrow$ TTT & S100F & Bladder & - & 23 \\
\hline $\mathrm{F} 170$ & $f$ & 35 & $\mathrm{~m}$ & & - & - & Abdomen & Bone & $10^{\dagger}$ \\
\hline F185 & $f$ & 56 & $\mathrm{~b}$ & & - & - & Abdomen & - & 10 \\
\hline F188 & $f$ & 52 & $b$ & $S D H D$ & $\mathrm{GAC} \rightarrow \mathrm{TAC}$ & D92Y & Abdomen & - & 38 \\
\hline F207 & $f$ & 63 & $\mathrm{~m}$ & $\begin{array}{l}S D H B \\
S D H D\end{array}$ & $\begin{aligned} \mathrm{TGC} & \rightarrow \mathrm{AGC} \\
A G C & \rightarrow A G T^{C}\end{aligned}$ & $\begin{array}{l}\text { C243S } \\
\text { S68S }\end{array}$ & Abdomen & Abdomen, bone & $10^{\dagger}$ \\
\hline F209 & $\mathrm{m}$ & 30 & $b$ & & - & - & Abdomen & - & 5 \\
\hline F218 & $\mathrm{u}$ & $\mathrm{u}$ & $\mathrm{m}$ & & - & - & $\mathrm{u}$ & Bone & $\mathrm{u}$ \\
\hline F219 & $\mathrm{u}$ & u & $\mathrm{m}$ & & - & - & $\mathrm{u}$ & Liver & $\mathrm{u}$ \\
\hline F220 & $\mathrm{u}$ & $\mathrm{u}$ & $\mathrm{m}$ & & - & - & Abdomen & Lymph node & $\mathrm{u}$ \\
\hline F221 & $\mathrm{u}$ & u & $\mathrm{m}$ & & - & - & u & $u$ & u \\
\hline F222 & $\mathrm{u}$ & u & $\mathrm{m}$ & & - & - & $\mathrm{u}$ & $\mathrm{u}$ & $\mathrm{u}$ \\
\hline
\end{tabular}

${ }^{a} m$, male; f, female.

${ }^{\mathrm{b}} \mathrm{b}$, benign; $\mathrm{m}$, malignant; $\mathrm{u}$, unknown.

${ }^{c}$ Nucleotide and amino acid changes representing polymorphisms are given in italics. The somatic mutation is depicted in bold.

${ }^{\dagger}$ Deceased.

as well, as loss of the wild-type allele was seen (van Nederveen et al. 2007). In addition, this amino acid was conserved throughout many species. Mutations in $S D H B$ S100 have also previously been described by Pollard et al. (2005) in a patient with PGL, and Neumann et al. (2004) reported a patient with an sPGL who had a $S D H B$ C101Y mutation.

Two polymorphisms were found in $S D H B$ : A6A and S163P. The A6A polymorphism was found in one patient (2\% of all patients) with an sPGL. A6A was previously reported as a polymorphism with a prevalence of $4 \%$ (NCBI: rs2746462), which is in concurrence with our data. The other $S D H B$ polymorphism found in our study was S163P (2\% of all patients), which was found in a patient with an SPGL. The frequency in our series was in the same range as the $2.3 \% \mathrm{~S} 163 \mathrm{P}$ substitutions found by Cascon et al. (2004) in a healthy control population.

Two previously described germline SDHD mutations were found in the sPGL group, D92Y and L95P
(Dannenberg et al. 2005). Both mutations are known as Dutch founder mutations in head and neck paragangliomas (Taschner et al. 2001). The patient with the D92Y mutation also had an adrenal bilateral PCC, 27 years earlier, which were surgically removed and included in our bilateral PCC series. The L95P mutation was found in a patient with a benign PCC, and after 12 years of followup, the patient was alive and well. Both patients are previously described by Dannenberg et al. (2005).

Two polymorphisms were observed in SDHD, H50R in two patients and S68S in one. Since the frequency of the H50R substitution in our series (4\% of all patients) is comparable with the frequency that has been reported in the literature for the normal population, we considered it a polymorphism (Perren et al. 2002, Cascon et al. 2003). The SDHD S68S variant was seen in two patients (one with sPGL and one with bilateral PCC) and has previously been described as a polymorphism (Cascon et al. 2004). 

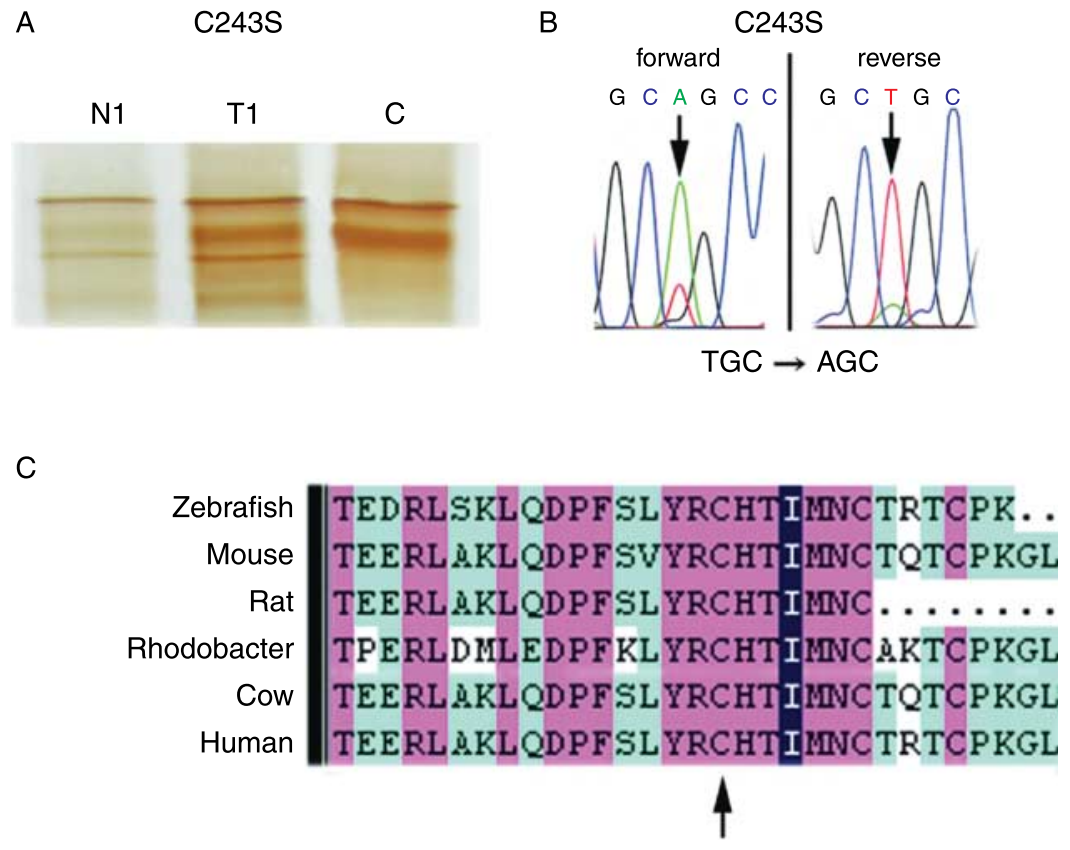

Figure 2 (A) Altered SDHB DGGE pattern in tumor (T1) and corresponding normal (N1) DNA from patient F207 compared with healthy control DNA $(C)$. Note the identical aberrant pattern in both tumor and normal DNA compared with healthy control DNA pattern, indicating germline aberration. (B) Patient F207 tumor DNA sequence result (forward and reverse) of the germline SDHB C243S mutation. Note the relative loss of the T nucleotide compared with the A nucleotide (in the forward sequence; arrow), indicating loss of the wild-type allele (with the A nucleotide) in the tumor. (C) Alignment of SDHB amino acid sequence (NCBI: NM_003000) of a variety of species. The arrow points to the highly conserved C243.

Interestingly, the $S D H B$ and $S D H D$ mutation frequencies found in this study are considerably lower $(8 \%$ for SDHB including the somatic mutation and $8 \%$ for $S D H D$ ) than that reported in the study of Amar et al. (2005) which were $29 \%$ for $S D H B$ and $12 \%$ for $S D H D$. This difference might be explained on the basis of geographical variation in mutation frequency, as has become evident from comparative studies (Gimenez-Roqueplo et al. 2006). Another study reported a mutation range of $30-41 \%$ of $S D H B$ mutations in a series of catecholamine-producing PGLs (Brouwers et al. 2006). This high mutation frequency could be due to a sample bias, as all PGLs were malignant, whereas only approximately half of our sPGLs were malignant. In addition, the technique used in our investigation cannot be used to detect all genetic changes in these candidate genes, i.e. it is not suitable for detecting large deletions, which have been demonstrated in VHL, SDHB, and SDHD (Maranchie et al. 2004, McWhinney et al. 2004, Cascon et al. 2005).

The nucleotide alterations of $S D H B$ and $S D H D$ discussed above are thought to be polymorphisms (SDHB A6A and S163P; SDHD H50R and S68S), because they have also been demonstrated in healthy controls. Though, it is striking that out of four patients with either a $S D H B$ mutation or polymorphism, three patients also had a polymorphism in SDHD (Tables 2 and 3). In our study, one patient with an sPGL harbored the $S D H B$ S163P polymorphism and the SDHD H50R. In addition, the sPGL with the $S D H B C 243$ S mutation also showed the SDHD S68S polymorphism. To test whether there was a relationship between $S D H B$ and $S D H D$ polymorphisms and PCC development, we screened an additional series of 89 normal DNA samples of patients with adrenal PCC for the SDHB S163P and SDHD H50R polymorphisms. However, we did not find additional patients with both S163P and H50R, suggesting that there is no relationship between the polymorphisms and the development of adrenal PCC (data not shown). For sPGL, this could not be assessed, due to the limited number of specimens available. Interestingly, $S D H B$ and $S D H D$ polymorphisms were recently demonstrated at increased frequency in patients with familial medullary thyroid carcinoma (Montani et al. 2005).

In most published series, usually only germline mutations in $S D H B$ and $S D H D$ have been found, especially since most studies have addressed germline DNA only. In this study, we have chosen to perform mutation analysis on DNA from tumor tissue and the corresponding normal tissue, in order not to miss somatic mutations. We found only a single somatic mutation, in the $S D H B$ gene, in our group of 58 patients, although it must be noted that the likelihood of finding such 
mutations in bilateral PCC is probably low. In our previous studies, we have shown that somatic mutations in RET and $V H L$ occur at a low, but not insignificant, frequency. In contrast, somatic $S D H B$ and $S D H D$ mutations are so far very rare. As such, mutation analysis directed at the detection of somatic mutations in these candidate genes appears not warranted.

In our study, we found $52 \%$ RET, $4 \% \mathrm{VHL}$, and $4 \%$ $S D H D$ germline mutations in 33 patients with bilateral PCC, and $8 \%$ SDHB and $8 \%$ SDHD mutations in 26 patients with sPGL. Amar et al. (2005) recently described $41 \%$ VHL $(n=17), 27 \%$ RET $(n=11)$, and $7 \% \operatorname{SDHD}(n=3)$ germline mutations in 41 patients with bilateral adrenal PCC. In addition, these authors found $7 \% \operatorname{VHL}(n=4), 29 \% \operatorname{SDHB}(n=17)$, and $12 \%$ $S D H D(n=7)$ mutations in 58 patients with sPGL. These results are not entirely in concurrence with our data. This occurrence is most likely due to geographical differences, as most of our patients were from the Netherlands, whereas all of the patients of Amar et al. (2005) were from France. In addition, geographical differences in mutation frequencies of the PCC susceptibility genes between France, Germany, and Italy have recently been shown by Gimenez-Roqueplo et al. (2006). In addition, the technique used in this investigation cannot be used to detect all genetic changes in these candidate genes, i.e. it is not suitable for detecting large deletions, which have been demonstrated in VHL, SDHB, and SDHD (Maranchie et al. 2004, McWhinney et al. 2004, Cascon et al. 2005).

In summary, we have performed mutation analysis on the PCC susceptibility genes RET, VHL, SDHB, and $S D H D$ in a series of bilateral adrenal PCC and SPGL. The bilateral adrenal PCC showed only germline RET, $V H L$, or $S D H D$ mutations and the sPGL only germline and somatic $S D H B$ or germline $S D H D$ mutations. Our results imply that it is advantageous to first test patients with bilateral PCC for mutations in RET, although, based on previous literature, simultaneous testing for $V H L$ and $S D H D$ appears justified, while patients with sPGL should be first tested for mutations in the $S D H B$ and $S D H D$ genes. In addition, the finding of rare somatic $S D H B$ gene mutations indicates that mutation analysis of tumor DNA should always be considered when germline mutations are not found.

\section{Acknowledgements}

The authors declare that there is no conflict of interest of financial or personal kind with respect to the present study. We thank Frank van der Panne for his assistance with the figures.

\section{References}

Ackrell BA 2002 Cytopathies involving mitochondrial complex II. Molecular Aspects of Medicine $\mathbf{2 3}$ 369-384.

Amar L, Bertherat J, Baudin E, Ajzenberg C, Bressac-de Paillerets B, Chabre O, Chamontin B, Delemer B, Giraud S, Murat A et al. 2005 Genetic testing in pheochromocytoma or functional paraganglioma. Journal of Clinical Oncology 23 8812-8818.

Baysal BE, Willett-Brozick JE, Lawrence EC, Drovdlic CM, Savul SA, McLeod DR, Yee HA, Brackmann DE, Slattery WH III, Myers EN et al. 2002 Prevalence of SDHB, $S D H C$, and $S D H D$ germline mutations in clinic patients with head and neck paragangliomas. Journal of Medical Genetics 39 178-183.

Benn DE, Gimenez-Roqueplo AP, Reilly JR, Bertherat J, Burgess J, Byth K, Croxson M, Dahia PL, Elston M, Gimm O et al. 2005 Clinical presentation and penetrance of pheochromocytoma/paraganglioma syndromes.

Journal of Clinical Endocrinology and Metabolism 91 827-836.

Brouwers FM, Eisenhofer G, Tao JJ, Kant JA, Adams KT, Linehan WM \& Pacak K 2006 High frequency of SDHB germline mutations in patients with malignant catecholamine-producing paragangliomas: implications for genetic testing. Journal of Clinical Endocrinology and Metabolism 91 4505-4509.

Bryant J, Farmer J, Kessler LJ, Townsend RR \& Nathanson KL 2003 Pheochromocytoma: the expanding genetic differential diagnosis. Journal of the National Cancer Institute 95 1196-1204.

Cascon A, Ruiz-Llorente S, Cebrian A, Leton R, Telleria D, Benitez J \& Robledo M 2003 G12S and H5OR variations are polymorphisms in the SDHD gene. Genes, Chromosomes and Cancer 37 220-221.

Cascon A, Ruiz-Llorente S, Fraga MF, Leton R, Telleria D, Sastre J, Diez JJ, Martinez Diaz-Guerra G, Diaz Perez JA, Benitez J et al. 2004 Genetic and epigenetic profile of sporadic pheochromocytomas. Journal of Medical Genetics 41 e30.

Cascon A, Montero-Conde C, Ruiz-Llorente S, Mercadillo F, Leton R, Rodriguez-Antona C, Martinez-Delgado B, Delgado M, Diez A, Rovira A et al. 2005 Gross SDHB deletions in patients with paraganglioma detected by multiplex PCR: a possible hot spot? Genes, Chromosomes and Cancer 45 213-219.

Dannenberg H, De Krijger RR, van der Harst E, Abbou M, Y IJ, Komminoth P \& Dinjens WN 2003

Von Hippel-Lindau gene alterations in sporadic benign and malignant pheochromocytomas. International Journal of Cancer 105 190-195.

Dannenberg H, van Nederveen FH, Abbou M, Verhofstad AA, Komminoth P, de Krijger RR \& Dinjens WN 2005 Clinical characteristics of pheochromocytoma patients with germline mutations in SDHD. Journal of Clinical Oncology 23 1894-1901. 
Eng C 1996 Seminars in medicine of the Beth Israel Hospital, Boston. The RET proto-oncogene in multiple endocrine neoplasia type 2 and Hirschsprung's disease. New England Journal of Medicine 335 943-951.

Gimenez-Roqueplo AP, Favier J, Rustin P, Rieubland C, Crespin M, Nau V, Khau Van Kien P, Corvol P, Plouin PF \& Jeunemaitre X 2003 Mutations in the $S D H B$ gene are associated with extra-adrenal and/or malignant phaeochromocytomas. Cancer Research 63 5615-5621.

Gimenez-Roqueplo AP, Lehnert H, Mannelli M, Neumann H, Opocher G, Maher ER \& Plouin PF 2006 Phaeochromocytoma, new genes and screening strategies. Clinical Endocrinology 65 699-705.

Gimm O 2005 Pheochromocytoma-associated syndromes: genes, proteins and functions of RET, VHL and SDHx. Familial Cancer 4 17-23.

van der Harst E, de Krijger RR, Dinjens WN, Weeks LE, Bonjer HJ, Bruining HA, Lamberts SW \& Koper JW $1998 a$ Germline mutations in the $v h l$ gene in patients presenting with phaeochromocytomas. International Journal of Cancer 77 337-340.

van der Harst E, de Krijger RR, Bruining HA, Lamberts SW, Bonjer HJ, Dinjes WN, Proye C, Koper JW, Bosman FT, Roth J et al. 1998 brognostic value of RET protooncogene point mutations in malignant and benign, sporadic phaeochromocytomas. International Journal of Cancer 79 537-540.

Komminoth P, Kunz E, Hiort O, Schroder S, Matias-Guiu X, Christiansen G, Roth J \& Heitz PU 1994 Detection of RET proto-oncogene point mutations in paraffin-embedded pheochromocytoma specimens by nonradioactive singlestrand conformation polymorphism analysis and direct sequencing. American Journal of Pathology 145 922-929.

Lenders JW, Eisenhofer G, Mannelli M \& Pacak K 2005 Phaeochromocytoma. Lancet 366 665-675.

Machens A, Gimm O, Hinze R, Hoppner W, Boehm BO \& Dralle H 2001 Genotype-phenotype correlations in hereditary medullary thyroid carcinoma: oncological features and biochemical properties. Journal of Clinical Endocrinology and Metabolism 86 1104-1109.

Machens A, Brauckhoff M, Holzhausen HJ, Thanh PN, Lehnert H \& Dralle H 2005 Codon-specific development of pheochromocytoma in multiple endocrine neoplasia type 2. Journal of Clinical Endocrinology and Metabolism 90 3999-4003.

Maier-Woelfle M, Brandle M, Komminoth P, Saremaslani P, Schmid S, Locher T, Heitz PU, Krull I, Galeazzi RL, Schmid C et al. 2004 A novel succinate dehydrogenase subunit B gene mutation, $H 132 P$, causes familial malignant sympathetic extraadrenal paragangliomas. Journal of Clinical Endocrinology and Metabolism 89 362-367.

Maranchie JK, Afonso A, Albert PS, Kalyandrug S, Phillips JL, Zhou S, Peterson J, Ghadimi BM, Hurley K, Riss J et al. 2004 Solid renal tumor severity in von Hippel Lindau disease is related to germline deletion length and location. Human Mutation 23 40-46.
McWhinney SR, Pilarski RT, Forrester SR, Schneider MC, Sarquis MM, Dias EP \& Eng C 2004 Large germline deletions of mitochondrial complex II subunits SDHB and SDHD in hereditary paraganglioma. Journal of Clinical Endocrinology and Metabolism 89 5694-5699.

Montani M, Schmitt AM, Schmid S, Locher T, Saremaslani P, Heitz PU, Komminoth P \& Perren A 2005 No mutations but an increased frequency of SDHx polymorphisms in patients with sporadic and familial medullary thyroid carcinoma. Endocrine-Related Cancer 12 1011-1016.

van Nederveen FH, Korpershoek E, Lenders JW, de Krijger RR \& Dinjens WNM 2007 Somatic SDHB mutation in an extra-adrenal pheochromocytoma. New England Journal of Medicine (in press).

Neumann HP, Hoegerle S, Manz T, Brenner K \& Iliopoulos O 2002 How many pathways to pheochromocytoma? Seminars in Nephrology 22 89-99.

Neumann HP, Pawlu C, Peczkowska M, Bausch B, McWhinney SR, Muresan M, Buchta M, Franke G, Klisch J, Bley TA et al. 2004 Distinct clinical features of paraganglioma syndromes associated with $S D H B$ and SDHD gene mutations. JAMA 292 943-951.

Peczkowska M \& Januszewicz A 2005 Multiple endocrine neoplasia type 2. Familial Cancer 4 25-36.

Perren A, Barghorn A, Schmid S, Saremaslani P, Roth J, Heitz PU \& Komminoth P 2002 Absence of somatic SDHD mutations in sporadic neuroendocrine tumors and detection of two germline variants in paraganglioma patients. Oncogene 21 7605-7608.

Pollard PJ, Briere JJ, Alam NA, Barwell J, Barclay E, Wortham NC, Hunt T, Mitchell M, Olpin S, Moat SJ et al. 2005 Accumulation of Krebs cycle intermediates and over-expression of HIF1alpha in tumours which result from germline $F H$ and $S D H$ mutations. Human Molecular Genetics 14 2231-2239.

Roman S 2004 Pheochromocytoma and functional paraganglioma. Current Opinion in Oncology 16 8-12.

Schiavi F, Boedeker CC, Bausch B, Peczkowska M, Gomez CF, Strassburg T, Pawlu C, Buchta M, Salzmann M, Hoffmann MM et al. 2005 Predictors and prevalence of paraganglioma syndrome associated with mutations of the SDHC gene. JAMA 294 2057-2063.

Taschner PE, Jansen JC, Baysal BE, Bosch A, Rosenberg EH, Brocker-Vriends AH, van Der Mey AG, van Ommen GJ, Cornelisse CJ \& Devilee P 2001 Nearly all hereditary paragangliomas in the Netherlands are caused by two founder mutations in the SDHD gene. Genes, Chromosomes and Cancer 31 274-281.

Thakker RV 2001 Multiple endocrine neoplasia. Hormone Research 56 67-72.

Young AL, Baysal BE, Deb A \& Young WF Jr 2002 Familial malignant catecholamine-secreting paraganglioma with prolonged survival associated with mutation in the succinate dehydrogenase B gene. Journal of Clinical Endocrinology and Metabolism 87 4101-4105. 